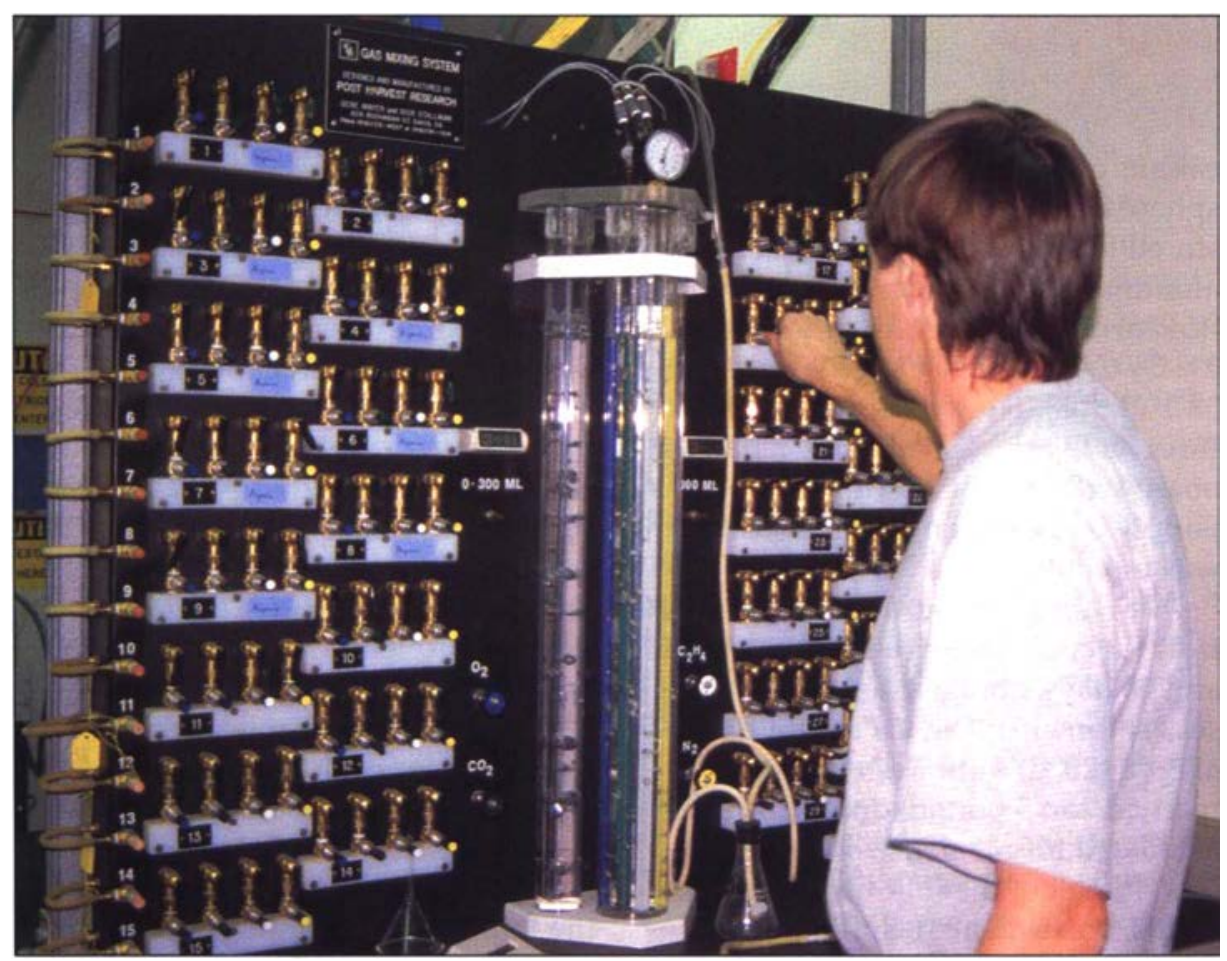

\title{
Peach size affects storage, market life
}

\author{
Carlos H. Crisosto \\ 口 David Garner \\ - Luis Cid \\ Kevin R. Day
}

During the 1995 season, large ( -275g), medium ( -175g) and small ( 125g) 'O'Henry' peaches were stored in either air, $5 \% \mathrm{CO}_{2}+$ $2 \% \mathrm{O}_{2}$ or $17 \% \mathrm{CO}_{2}+6 \% \mathrm{O}_{2}$ at $38^{\circ} \mathrm{F}$ $\left(3.3^{\circ} \mathrm{C}\right)$. Large 'O'Henry' peaches benefited more from the $17 \% \mathrm{CO}_{2}$ $+6 \% \mathrm{O}_{2}$ than from either the $5 \%$ $\mathrm{CO}_{2}+2 \% \mathrm{O}_{2}$ or the air storage treatment. During the 1996 season, large, medium and small 'Elegant Lady' and 'O'Henry' peaches were stored in air or in $17 \% \mathrm{CO}_{2}+6 \% \mathrm{O}_{2}$ at either $32{ }^{\circ} \mathrm{F}$ $\left(0^{\circ} \mathrm{C}\right)$ or $38^{\circ} \mathrm{F}$. Fruit size, storage atmosphere and temperature all had significant effects on chilling injury development. Small peaches stored in air at $32^{\circ} \mathrm{F}$ had a longer market life than large fruit. At both storage temperatures, large 'Elegant Lady' and 'O'Henry' peaches had a longer market life under controlled atmosphere than under air storage.
However, at $38^{\circ} \mathrm{F}$, small 'Elegant Lady' fruit in controlled atmosphere showed browning in the flesh. This suggests that $17 \% \mathrm{CO}_{2}$ $+6 \% \mathrm{O}_{2}$ may induce flesh browning in small 'Elegant Lady' peaches. In both years, lack of juiciness (mealiness/leatheriness) was observed before the development of flesh browning. Thus market life depended on the incidence of mealiness/leatheriness rather than on flesh browning.

One of the most frequent complaints about apricots, peaches, nectarines, prunes and plums by consumers and wholesalers is lack of juiciness (flesh mealiness/leatheriness), flesh browning, black pit cavity, flesh translucency, red pigment accumulation (bleeding) and loss of flavor. These symptoms are caused by a physiological disorder known as internal breakdown or chilling injury. The onset and

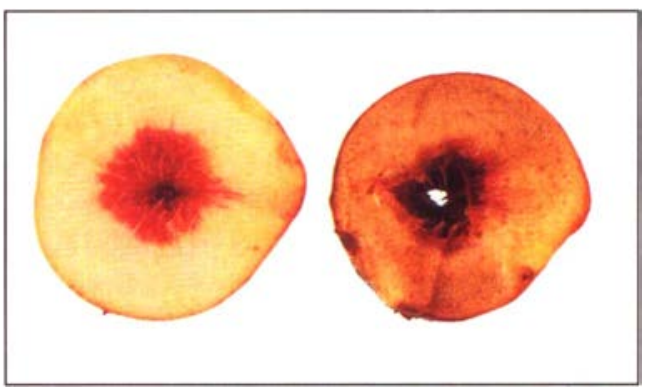

$\Delta$ The 'Elegant Lady' peach on the right shows symptoms of $\mathrm{Cl}$ (internal browning), in comparison with the healthy fruit on the left.

Gas mixing board with micrometering vaives used to prepare different carbon dioxide and oxygen combinations.

intensity of internal breakdown symptoms during postharvest handling varies according to cultivar, preharvest cultural practices, growing season environmental conditions and postharvest handling. These chilling injury symptoms normally appear during prolonged cold storage or after ripening at room temperature following cold storage. This physiological disorder is the main limitation on long-term storage and shipment to distant markets for chilling injury-susceptible peach and nectarine cultivars. In chilling injury-susceptible stone fruit, the greatest development of internal breakdown symptoms occurs at storage temperatures between $36^{\circ} \mathrm{F}\left(2.2^{\circ} \mathrm{C}\right)$ and $46^{\circ} \mathrm{F}\left(7.8^{\circ} \mathrm{C}\right)$. These temperatures are typical during transport and warehouse-handling operations.

Controlled atmosphere (CA) conditions have been claimed to delay chilling injury and extend postharvest life. A $17 \%$ carbon dioxide $\left(\mathrm{CO}_{2}\right)$ combined with $6 \%$ oxygen $\left(\mathrm{O}_{2}\right)$ atmosphere balanced in nitrogen is used commercially during overseas shipment by the TransFRESH Corp. A $5 \% \mathrm{CO}_{2}$ combined with $2 \% \mathrm{O}_{2}$ atmosphere has also been recommended for long-term shipment/storage (Carrier Corp. 1995; Kader 1992). Despite commercial use of these CA conditions, the reduction of chilling injury symptoms have been erratic and unreliable.

Prior research (Crisosto et al. 1997, 1999) has led us to believe that CA storage performance can be improved once we better understand the relationships between cultivar susceptibil- 
ity and "orchard factors." In this study, we investigated the role of fruit size on peach internal breakdown susceptibility under air and CA conditions. However, cultural practices such as irrigation, fruit canopy position and leaf nitrogen status also affect, in low intensity, the onset of internal breakdown symptoms.

\section{5 season}

As a first step, we compared the market life of 'O'Henry' peaches stored at $38^{\circ} \mathrm{F}\left(3.3^{\circ} \mathrm{C}\right)$ under ethylenefree air or $5 \% \mathrm{CO}_{2}+2 \% \mathrm{O}_{2}$ or $17 \% \mathrm{CO}_{2}$ $+6 \% \mathrm{O}_{2}$. We collected large $(\sim 275 \mathrm{~g})$, medium $(\sim 175 \mathrm{~g})$ and small $(\sim 125 \mathrm{~g})$ peaches harvested at commercial maturity from a commercial packinghouse in Reedley immediately after packaging. During packaging, iprodione (Rovral) fungicide and wax were applied to the fruit. Fruit were transported within 2 hours to the F. Gordon Mitchell Postharvest Laboratory at the Kearney Agricultural Center and forced-air cooled overnight to a pulp temperature of approximately $32^{\circ} \mathrm{F}\left(0^{\circ} \mathrm{C}\right)$. After cooling, the fruit were stored at $32^{\circ} \mathrm{F}\left(0^{\circ} \mathrm{C}\right)$ for 4 days, then subdivided into four repli- cations of 80 fruit for each size/atmosphere condition. The fruit were stored in 89-gallon (338-liter) sealed aluminum tanks under a continuous flow of ethylene-free air or $5 \% \mathrm{CO}_{2}+$ $2 \% \mathrm{O}_{2} \mathrm{CA}$ or $17 \% \mathrm{CO}_{2}+6 \% \mathrm{O}_{2} \mathrm{CA}$ at $38^{\circ} \mathrm{F}\left(3.3^{\circ} \mathrm{C}\right)$. Flow rates and gas mixtures were established using a mixing board with micrometering valves. Supply and exhaust gas composition was monitored.

We withdrew four replications of 20 fruit for each size/treatment after 0,10 and 20 days storage (simulating overseas shipment). The fruit were ripened at $68^{\circ} \mathrm{F}\left(20^{\circ} \mathrm{C}\right)$ until flesh firmness reached 2 to 3 pounds-force (lbf), then evaluated for incidence of chilling injury. For all of the following experiments, we evaluated chilling injury symptoms as flesh browning (FB) (score $1-6$, with $1=$ no $\mathrm{FB}$ to $6=$ severe FB); texture (juicy, mealy or leathery); and bleeding (light, moderate or severe). At the same time, an informal taste panel evaluated the presence of "off flavors." The end of market life was determined when more than $25 \%$ of the fruit were mealy or $15 \%$ of the fruit had an FB score of $3(25 \% \mathrm{FB})$ or greater.
TABLE 1. Influence of storage atmosphere and fruit size on ripe 'O'Henry' peach internal breakdown after storage for 10 and 20 days at $3.3^{\circ} \mathrm{C}$

\begin{tabular}{|c|c|c|c|c|c|}
\hline $\begin{array}{l}\text { Storage } \\
\text { time }\end{array}$ & $\begin{array}{l}\text { Fruit } \\
\text { size }\end{array}$ & $\begin{array}{c}\text { Storage } \\
\text { atmosphere }\end{array}$ & $\begin{array}{l}\text { Juicy } \\
\text { fruit }\end{array}$ & $\begin{array}{c}\text { Flesh* } \\
\text { browning }\end{array}$ & $\begin{array}{c}\text { Flesh } \\
\text { bleeding }\end{array}$ \\
\hline & grams & $\% \mathrm{CO}_{2}-\% \mathrm{O}_{2}$ & ....................... & ..... \% .............. & .................. \\
\hline 10 Days & $\begin{array}{l}\text { Large } \\
(\sim 275) \\
\text { Medium } \\
(\sim 175) \\
\text { Small } \\
(\sim 125)\end{array}$ & $\begin{array}{c}\text { Air } \\
5 \% \mathrm{CO}_{2}+3 \% \mathrm{O}_{2} \\
17 \% \mathrm{CO}_{2}+6 \% \mathrm{O}_{2} \\
\text { Air } \\
5 \% \mathrm{CO}_{2}+3 \% \mathrm{O}_{2} \\
17 \% \mathrm{CO}_{2}+6 \% \mathrm{O}_{2} \\
\text { Air } \\
5 \% \mathrm{CO}_{2}+3 \% \mathrm{O}_{2} \\
17 \% \mathrm{CO}_{2}+6 \% \mathrm{O}_{2}\end{array}$ & $\begin{array}{r}50.4 \\
68.8 \\
98.8 \\
88.8 \\
92.5 \\
100.0 \\
90.0 \\
95.0 \\
97.5\end{array}$ & $\begin{array}{r}36.4 \\
15.6 \\
0.0 \\
8.8 \\
2.6 \\
0.0 \\
2.5 \\
0.0 \\
1.3\end{array}$ & $\begin{array}{l}2.4 \\
1.3 \\
1.3 \\
2.5 \\
1.3 \\
0.0 \\
0.0 \\
0.0 \\
0.0\end{array}$ \\
\hline $\begin{array}{l}\text { P-value } \\
\text { LSD }_{0.05}\end{array}$ & & & $\begin{array}{l}0.0001 \\
12.3\end{array}$ & $\begin{array}{l}0.0001 \\
9.8\end{array}$ & $\begin{array}{l}0.69 \\
\text { N.S. }\end{array}$ \\
\hline 20 Days & $\begin{array}{c}\text { Large } \\
(\sim 275) \\
\text { Medium } \\
(\sim 175) \\
\text { Small } \\
(\sim 125)\end{array}$ & $\begin{array}{c}\text { Air } \\
5 \% \mathrm{CO}_{2}+3 \% \mathrm{O}_{2} \\
17 \% \mathrm{CO}_{2}+6 \% \mathrm{O}_{2} \\
\text { Air } \\
5 \% \mathrm{CO}_{2}+3 \% \mathrm{O}_{2} \\
17 \% \mathrm{CO}_{2}+6 \% \mathrm{O}_{2} \\
\text { Air } \\
5 \% \mathrm{CO}_{2}+3 \% \mathrm{O}_{2} \\
17 \% \mathrm{CO}_{2}+6 \% \mathrm{O}_{2}\end{array}$ & $\begin{array}{r}7.6 \\
7.3 \\
56.4 \\
50.6 \\
39.8 \\
65.5 \\
81.5 \\
70.4 \\
79.1\end{array}$ & $\begin{array}{r}87.8 \\
83.5 \\
23.0 \\
31.4 \\
37.8 \\
18.8 \\
15.3 \\
20.7 \\
7.4\end{array}$ & $\begin{array}{r}0.0 \\
0.0 \\
20.6 \\
1.4 \\
0.0 \\
6.7 \\
0.0 \\
0.0 \\
5.7\end{array}$ \\
\hline $\begin{array}{l}\text { P-value } \\
\text { LSD }_{0.05}\end{array}$ & & & $\begin{array}{l}0.0001 \\
18.0\end{array}$ & $\begin{array}{l}0.0001 \\
16.5\end{array}$ & $\begin{array}{l}0.0001 \\
8.4\end{array}$ \\
\hline
\end{tabular}

"Fruit with $25 \%$ flesh browning

\section{Season}

Based on the results of our 1995 research, only the ethylene-free air and $17 \% \mathrm{CO}_{2}+6 \% \mathrm{O}_{2} \mathrm{CA}$ treatments were used in these tests. Large, medium and small 'Elegant Lady' and 'O'Henry' peaches were collected from the packinghouse, cooled and stored at $32^{\circ} \mathrm{F}\left(0^{\circ} \mathrm{C}\right)$ for 4 days as described previously. Stone fruit were stored in 89-gallon (338-liter) sealed aluminum tanks under a continuous flow of ethylene-free air or $17 \% \mathrm{CO}_{2}$ $+6 \% \mathrm{O}_{2} \mathrm{CA}$ at either $32^{\circ} \mathrm{F}\left(0^{\circ} \mathrm{C}\right)$ or $38^{\circ} \mathrm{F}\left(3.3^{\circ} \mathrm{C}\right)$. Four replications of 20 fruit each for each size/treatment/ temperature were withdrawn after 0 , 7,14 and 21 days storage (simulating overseas shipments). We evaluated the fruit's chilling injury symptoms after ripening.

We used a factorial design arranged in a split-split plot in this experiment. The design included two main treatments (air and controlled atmosphere storage conditions) and three subtreatments (small, medium and large fruit) at $32^{\circ} \mathrm{F}\left(0^{\circ} \mathrm{C}\right)$ and $38^{\circ} \mathrm{F}$ $\left(3.3^{\circ} \mathrm{C}\right)$. The data were subjected to analysis of variance (ANOVA) prior to the Least Significant Differences (LSD) mean separation using the SAS program.

\section{Size plays a role in 1995}

Fruit size played an important role in chilling injury (mealiness,

leatheriness and FB) development under air and CA storage conditions for 'O'Henry' peaches (table 1). After 10 days of air storage, $50 \%$ of large, $89 \%$ of medium and $90 \%$ of small fruit remained juicy. FB incidence was $36 \%$ for large, $9 \%$ for medium and $3 \%$ for small fruit. After 20 days of air storage, $8 \%$ of the large fruit were juicy and $88 \%$ had FB. Medium and small fruit in air storage had $51 \%$ and $82 \%$ remaining juicy, respectively. FB was present in $31 \%$ and $15 \%$ of the medium and small size fruit, respectively. In both air and CA stored fruit, mealiness symptoms became visible earlier than FB symptoms. FB symptoms developed earlier and more intensely in large fruit than in medium and small fruit. 
After 10 and 20 days storage, a significantly higher percentage of large fruit remained juicy and had less $\mathrm{FB}$ in the $17 \% \mathrm{CO}_{2}+6 \% \mathrm{O}_{2} \mathrm{CA}$ treatment than in the $5 \% \mathrm{CO}_{2}+2 \% \mathrm{O}_{2} \mathrm{CA}$ treatment or the air treatment. Fifty-six percent of the large fruit remained juicy and $23 \%$ had FB in the $17 \% \mathrm{CO}_{2}$ $+6 \% \mathrm{O}_{2}$ treatment after 20 days of storage. In both the air and $5 \% \mathrm{CO}_{2}+$ $3 \% \mathrm{O}_{2}$ CA storage, less than $8 \%$ of the fruit remained juicy and more than $80 \%$ had FB after this same 20 -day storage period. More of the medium fruit remained juicy and had a lower incidence of $\mathrm{FB}$ in the $17 \% \mathrm{CO}_{2}+6 \%$ $\mathrm{O}_{2} \mathrm{CA}$ treatment than in the $5 \% \mathrm{CO}_{2}+$ $2 \% \mathrm{O}_{2} \mathrm{CA}$ or air treatment after 10 days of storage. After 20 days of storage, juiciness and FB incidence of medium fruit were similar in all storage conditions. For the small fruit, storage atmosphere did not have a significant effect on the percentage remaining juicy after 10 or 20 days. The incidence of flesh bleeding was low, and it was not affected by fruit size or storage time under air storage conditions. Large fruit had a $21 \%$ incidence of flesh bleeding after 20 days storage in $17 \% \mathrm{CO}_{2}+6 \% \mathrm{O}_{2} \mathrm{CA}$.

\section{Chilling injury related to size, 1996}

The incidence of chilling injury was related to fruit size and storage conditions. After 14 days at $32^{\circ} \mathrm{F}\left(0^{\circ} \mathrm{C}\right)$, large CA-stored fruit had a higher percentage remaining juicy $(87 \%)$ than large air-stored fruit $(21 \%)$. With large fruit, CA storage at $32^{\circ} \mathrm{F}\left(0^{\circ} \mathrm{C}\right)$ was necessary to maintain a high percentage of juicy fruit after 14 days. After 21 days storage in air at $32^{\circ} \mathrm{F}\left(0^{\circ} \mathrm{C}\right)$, only $21 \%$ of the large size fruit were juicy, compared to $67 \%$ of the CA-stored fruit (fig. 1). More than $85 \%$ of small and medium 'Elegant Lady' fruit were juicy under $\mathrm{CA}\left(17 \% \mathrm{CO}_{2}+6 \% \mathrm{O}_{2}\right)$ at $0^{\circ} \mathrm{C}$, even after 21 days storage.

At $38^{\circ} \mathrm{F}\left(3.3^{\circ} \mathrm{C}\right)$, 'Elegant Lady' fruit developed mealy/leathery flesh in all three sizes tested. The first symptoms became visible on the large air-stored fruit after 7 days and for medium and small sizes after 14 days. In the large fruit, CA significantly delayed the development of chilling injury symp- toms. After 14 days, $75 \%$ of the large CA-stored fruit remained juicy, as compared to $31 \%$ of the large fruit from air storage. After 21 days, there was no difference between the large CA-stored and air-stored fruit with respect to juiciness. Medium CA-stored fruit had $75 \%$ and $54 \%$ remaining juicy after 14 and 21 days storage, respectively. In air storage, only $31 \%$ remained juicy after 14 days and $8 \%$ after 21 days storage. CA storage did not have any significant benefits for small fruit. In fact, the percentage of small fruit remaining juicy was lower in CA storage than in air storage after 21 days.

In 'Elegant Lady' peaches stored at $32^{\circ} \mathrm{F}\left(0^{\circ} \mathrm{C}\right)$, FB became visible after 21 days only in the large fruit. CA storage limited the development of FB in large fruit. Small and medium 'Elegant Lady' peaches did not develop any FB when stored at $32^{\circ} \mathrm{F}\left(0^{\circ} \mathrm{C}\right)$ (data not shown). In fruit stored at $38^{\circ} \mathrm{F}\left(3.3^{\circ} \mathrm{C}\right)$, FB appeared after 14 days in large peaches and after 21 days in medium and small peaches. $\mathrm{CA}\left(17 \% \mathrm{CO}_{2}+6 \%\right.$ $\mathrm{O}_{2}$ ) reduced $\mathrm{FB}$ development in medium and large fruit. However, flesh browning was observed in the small fruit when stored under $\mathrm{CA}$ at $38^{\circ} \mathrm{F}$ $\left(3.3^{\circ} \mathrm{C}\right)$ for longer than 14 days. Further studies need to be carried out to determine if these symptoms in small 'Elegant Lady' fruit are a consequence of high $\mathrm{CO}_{2}$ and/or low oxygen injury.

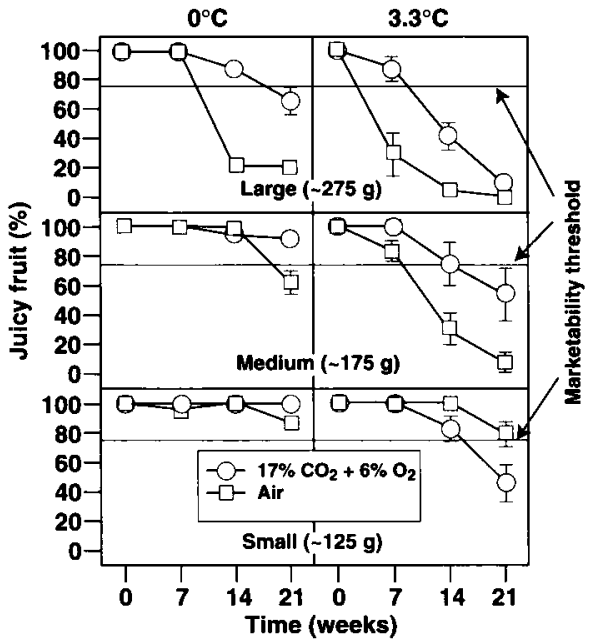

Fig. 1. Influence of temperature, storage atmosphere and fruit size on 'Elegant Lady' peach juiciness, 1996. Vertical bars represent +SE.
CA storage was necessary to maintain the juiciness of large ' $\mathrm{O}^{\prime} \mathrm{Henry}^{\prime}$ peaches. After 14 days at $32^{\circ} \mathrm{F}\left(0^{\circ} \mathrm{C}\right)$, a higher percentage of large CA-stored fruit remained juicy $(100 \%)$ than of large air-stored fruit $(63 \%)$. After 21 days at $32^{\circ} \mathrm{F}\left(0^{\circ} \mathrm{C}\right)$, large CA-stored fruit still had a higher percentage remaining juicy $(83 \%)$ than fruit from the air-storage treatment $(4 \%)$. After 21 days at $32^{\circ} \mathrm{F}\left(0^{\circ} \mathrm{C}\right), 92 \%$ of the medium fruit stored under $C A$ remained juicy, compared to $45 \%$ of the medium fruit stored in air. For small ' $\mathrm{O}$ 'Henry' fruit stored under $\mathrm{CA}$ at $32^{\circ} \mathrm{F}\left(0^{\circ} \mathrm{C}\right)$, chilling injury symptoms did not develop at important levels even after 21 days (fig. 2).

All three sizes of 'O'Henry' peaches showed symptoms of chilling injury when stored at $38^{\circ} \mathrm{F}\left(3.3^{\circ} \mathrm{C}\right)$. After 7 days in air storage, $62 \%$ of the large, $84 \%$ of the medium and $92 \%$ of the small fruit were juicy (fig. 2). With large fruit, CA provided significant protection against development of chilling injury. After 14 days, $77 \%$ of CA-stored fruit were juicy, as compared to $17 \%$ of air-stored fruit. After 21 days, it did not make any difference with respect to the percentage remaining juicy whether the fruit were stored in CA or air. With the medium CAstored fruit, $83 \%$ and $57 \%$ remained juicy after 14 and 21 days storage in CA, respectively. In air storage, $25 \%$ and $19 \%$ remained juicy after 14 and

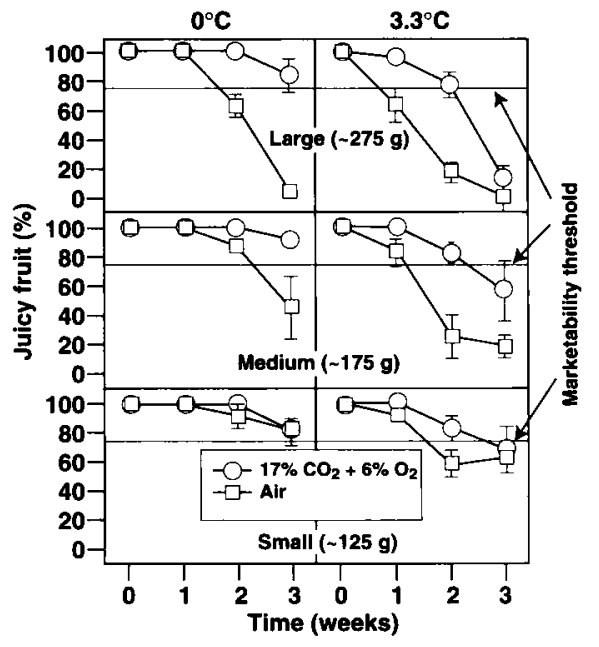

Fig. 2. Influence of temperature, storage atmosphere and fruit size on 'O'Henry' peach juiciness, 1996. Vertical bars represent +SE. 


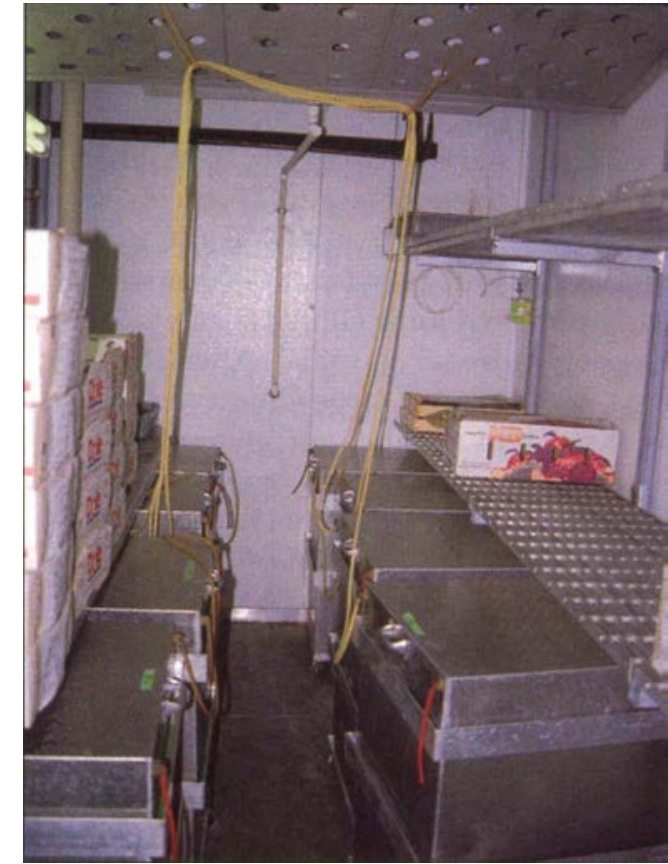

Controlled environment room with aluminum tanks containing boxes of peaches. Controlled atmospheres prepared with the mixing board were introduced into the tanks.

21 days, respectively. CA storage did not have any important benefit for small fruit.

\section{No flesh browning at $32^{\circ} \mathrm{F}$ in $\mathrm{CA}$}

FB symptoms were not visible in the three sizes of ' $\mathrm{O}$ 'Henry' peaches stored under $\mathrm{CA}$ conditions at $32^{\circ} \mathrm{F}$ $\left(0^{\circ} \mathrm{C}\right)$ for 21 days. Small and medium fruit did not develop any FB when stored in air at $32^{\circ} \mathrm{F}\left(0^{\circ} \mathrm{C}\right)$ for 14 days (data not shown). After 21 days in air storage, $100 \%$ of the large, $59 \%$ of the medium and $13 \%$ of the small fruit had FB. FB appeared after 14 days in all sizes of ' $\mathrm{O}$ ' Henry' peaches stored in air at $38^{\circ} \mathrm{F}\left(3.3^{\circ} \mathrm{C}\right)$ (data not shown). After 21 days air storage, $100 \%$ of the large fruit, $85 \%$ of the medium fruit and $42 \%$ of the small fruit had FB. After 21 days, the $\mathrm{CA}\left(17 \% \mathrm{CO}_{2}+6 \% \mathrm{O}_{2}\right)$ treatment reduced FB development for medium and large fruit to $67 \%$ and $43 \%$, respectively.

In all of these tests, fruit lost its juiciness at least 1 week before browning appeared. This agrees with observations over the last 5 years of fruit grown in the San Joaquin Valley (Crisosto et al. 1999). For this reason, we consider lack of juiciness (mealiness or leatheriness) to be a more accurate indicator of internal breakdown than FB. Trained panelists detected the lack of juiciness and "off flavors" of 'Elegant Lady' and 'O'Henry' fruit before expression of visible chilling injury symptoms (data not shown).

We used regression equations to predict market life of 'Elegant Lady' and ' $\mathrm{O}^{\prime} \mathrm{Henry}$ ' peaches stored at $32^{\circ} \mathrm{F}$ $\left(0^{\circ} \mathrm{C}\right)$ or $38^{\circ} \mathrm{F}\left(3.3^{\circ} \mathrm{C}\right)$ in air or CA. Predicted market life was based on incidence of chilling injury for both peach cultivars, but does not include the 4 days storage at $32^{\circ} \mathrm{F}\left(0^{\circ} \mathrm{C}\right)$ prior to the main storage treatment. Under airstorage conditions, predicted maximum market life at $32^{\circ} \mathrm{F}\left(0^{\circ} \mathrm{C}\right)$ of large, medium and small 'Elegant Lady' peaches was 9,19 and $21+$ days, respectively. Under CA-storage conditions, predicted maximum market life at $32^{\circ} \mathrm{F}\left(0^{\circ} \mathrm{C}\right)$ of large, medium and small 'Elegant Lady' fruit was 19, 21+ and $21+$ days, respectively. The three similar sizes of ' $\mathrm{O}$ 'Henry' fruit lasted 13,16 and $21+$ days in air storage at $32^{\circ} \mathrm{F}\left(0^{\circ} \mathrm{C}\right)$, respectively. All three sizes of 'O'Henry' fruit lasted $21+$ days in CA storage at $32^{\circ} \mathrm{F}\left(0^{\circ} \mathrm{C}\right)$.

The predicted market life of ' $\mathrm{El}$ egant Lady' in air at $38^{\circ} \mathrm{F}\left(3.3^{\circ} \mathrm{C}\right)$ (minimum market life) was 4,8 and 21 days for large, medium and small sizes, respectively. The predicted minimum market life of 'Elegant Lady' fruit in CA was 9,15 and 16 days for sizes large, medium and small, respectively. Large, medium and small ' $\mathrm{O}$ 'Henry' fruit stored in air at $38^{\circ} \mathrm{F}$ $\left(3.3^{\circ} \mathrm{C}\right)$ had a minimum market life of 5,6 and 12 days, respectively. Large, medium and small 'O'Henry' fruit stored in $\mathrm{CA}$ at $38^{\circ} \mathrm{F}\left(3.3^{\circ} \mathrm{C}\right)$ had a predicted minimum market life of 14,16 and 18 days, respectively.

\section{Injury occurs faster at $38^{\circ} \mathrm{F}$}

Chilling injury symptoms developed more rapidly and with greater intensity at $38^{\circ} \mathrm{F}\left(3.3^{\circ} \mathrm{C}\right)$ than at $32^{\circ} \mathrm{F}$ $\left(0^{\circ} \mathrm{C}\right)$. In all of the cases, fruit mealiness/ leatheriness symptoms developed earlier than FB.

Fruit size influenced the onset and intensity of chilling injury, and thus influenced fruit market life potential. Large fruit developed chilling injury symptoms earlier and with greater intensity than medium and small fruit under the two storage temperature conditions.
The $17 \% \mathrm{CO}_{2}+6 \% \mathrm{O}_{2}$ controlled atmosphere applied constantly was more effective than the $5 \% \mathrm{CO}_{2}+2 \%$ $\mathrm{O}_{2}$ controlled atmosphere at delaying symptoms of chilling injury for medium and large fruit.

A continuously applied controlled atmosphere $\left(17 \% \mathrm{CO}_{2}+6 \% \mathrm{O}_{2}\right)$ was not beneficial for the storage of small 'Elegant Lady' or ' $\mathrm{O}^{\prime}$ Henry' peaches. Furthermore, at $38^{\circ} \mathrm{F}\left(3.3^{\circ} \mathrm{C}\right)$, small ' $\mathrm{El}-$ egant Lady' peaches developed chilling injury earlier and with greater intensity in controlled atmosphere than in air storage.

C.H. Crisosto is Postharvest Physiologist and D. Garner is Staff Research Associate, Kearney Agricultural Center. L. Cid is Professor, University of Concepcion, Department of Mathematics, Concepción, Chile. K.R. Day is Tree Fruit Farm Advisor, UCCE, Tulare County.

\section{Further reading}

Carrier Corporation. 1995. Controlled Atmosphere Handbook: A Guide for Shipment of Perishable Cargo in Refrigerated Containers. Syracuse, New York: Carrier Corporation. $93 \mathrm{p}$.

Crisosto $\mathrm{CH}$, Johnson RS, DeJong T, Day KR. 1997. Orchard factors affecting postharvest stone fruit quality. Hort Science 32:820-3.

Crisosto CH, Mitchell FG, Ju Z. 1999. Susceptibility to chilling injury of peach, nectarine and plum cultivars grown in California. Hort Science (in press).

Kader, AA. 1992. Modified atmospheres during transport and storage, p. 85-92. In: AA Kader (ed.). Postharvest technology of horticultural crops, Publication 3311. University of California, Division of Agriculture and Natural Resources.

Kader AA. 1997. Fruit other than apples and pears, p. 26. In: AA Kader (ed.). Seventh International Controlled Atmosphere Research Conference. Postharvest Horticultural Series, No. 17.

Kader AA, El-Goorani MA, Sommer NF. 1982. Postharvest decay, respiration, ethylene production, and quality of peaches held in controlled atmospheres with added carbon monoxide. J Amer Soc Hort Sci 107:856-9.

Rushing JW, Dinamarca A. 1993. Simulated shipment of peaches, plums, and nectarines under controlled atmospheres, p. 202 22. In: Proceedings of the International Controlled Atmosphere Resources Conference, NRAES-71. Ithaca, NY: Cornell University.

Truter $A B$ and Combrink JC. 1992. Controlled atmosphere storage of peaches, nectarines, and plums. J S Afr Soc Hort Sci 2:10-3

Wade NL. 1981. Effects of storage atmosphere, temperature, and calcium on low temperature injury of peach fruit. Scientia Hort 15:145-54. 